\title{
Amperometric Enzyme Electrode for L-Lactate with the Use of Lipid-Modified Lactate Oxidase
}

\author{
Fumio MIZUTANI*, Soichi YABUKI and Tatsuo KATSURA \\ Received February 10, 1993 ; Accepted March 29, 1993
}

\section{INTRODUCTION}

In conventional amperometric enzyme electrodes, at least two membranes are placed on the surface of base electrodes: one is an immobilized enzyme membrane and the other is a dialysis membrane for preventing electrochemical interferences and electrode fouling. Cellulose acetate is commonly used as a semipermeable and protective coating on enzyme electrodes 1,2$)$. The application of a cellulose acetate membrane to the matrix for enzyme immobilization is an interesting approach to realizing enzyme electrodes with simple membrane structure. In order to prepare such a cellulose acetate-based system, the use of lipid-modified enzyme ${ }^{3}$ ), instead of native enzyme, is considered to be suitable ${ }^{4)}$ : the water-insoluble, modified enzyme molecules can be far more stably immobilized in the polymer matrix.

In this paper, we describe the preparation and the use of an amperometric L-lactate-sensing electrode with a lipid-modified lactate oxidase and cellulose acetate coating. The assay of $\mathrm{L}$-lactate is necessary in clinical and industrial food laboratories.

\section{EXPERIMENTAL}

Lactate oxidase (LOD, Asahi Chemical Industry) modified with an amphiphile [N-( $\alpha$-trimethylammonioacetyl)-didodecyl-L-glutamate chloride, Sogo Pharmaceutical] was prepared according to the procedure of Okahata et al ${ }^{3)}$; an aqueous solution of LOD was mixed with an aqueous dispersion of the amphiphile, and the precipitate formed after incubation of the mixture at $4^{\circ} \mathrm{C}$ for $24 \mathrm{~h}$ was lyophilized. The cataionic amphiphile was useful to modify the surface of anionically-charged LOD molecule (isoelectric point, $\mathrm{pH}$ 4.6). The LOD content in the modified enzyme was detrermined by

National Institute of Bioscience and HumanTechnology, Higashi, Tsukuba, Ibaraki 305

key words: Amperometry, Enzyme electrode, Modified enzyme, L-Lactate. measuring the absorption by flavin adenine dinucleotide (FAD) in a benzene solution of the product at $450 \mathrm{~nm}$. The enzyme activities of the modified and unmodified LOD were measured by using a peroxidase-phenol-4-aminoantipyrine chromogenic system. The solution (or dispersed medium in the case of the modified enzyme) used for measuring LOD activity was a $0.1 \mathrm{M}$ potassium phosphate buffer solution ( $\mathrm{pH} 7,25^{\circ} \mathrm{C}$ ).

A benzene solution containing the modified enzyme was placed on the surface of a glassy carbon electrode (Bioanalytical Systems, $3 \mathrm{~mm}$ in diameter) and the solvent was allowed to evaporate. The surface density of the modified enzyme on the electrode was $1.4 \mathrm{mg} \mathrm{cm}^{-2}$. Then a cellulose acetate coating was made by dip coating the electrode in an acetone solution of cellulose acetate $[1 \%(w / v)]$. The thickness of the modified LOD-cellulose acetate layer was several microns. The enzyme electrode thus prepared, an $\mathrm{Ag} / \mathrm{AgCl}$ electrode, and a platinum wire served as working, reference, and auxiliary electrodes, respectively. These electrodes were immersed in a test solution $(0.1 \mathrm{M}$ potassium phosphate buffer, $\mathrm{pH} 7,10 \mathrm{ml}, 25^{\circ} \mathrm{C}$ ). The solution was saturated with air and stirred by using a magnetic bar. The enzyme electrode was stored in the solution at $4^{\circ} \mathrm{C}$ when not in use.

\section{RESULTS AND DISCUSSION}

The LOD content in the lyophilized powder of the modified enzyme was calculated to be $30 \%$. The LOD activity of the modified enzyme was determined to be $9.1 \mathrm{U} \mathrm{mg}^{-1}$ solid, which corresponded to $30 \mathrm{U}$ $\mathrm{mg}^{-1}$ LOD. The LOD activity of the unmodified enzyme was determined to be $32 \mathrm{U} \mathrm{mg}^{-1}$. These results show that enzyme activity does not decrease during the modification process.

Figure 1 shows response curves on the enzyme electrode. The potential of the electrode was set at $0.9 \mathrm{~V}$ vs. $\mathrm{Ag} / \mathrm{AgCl}$. The current increased immediately after the addition of L-lactate and 


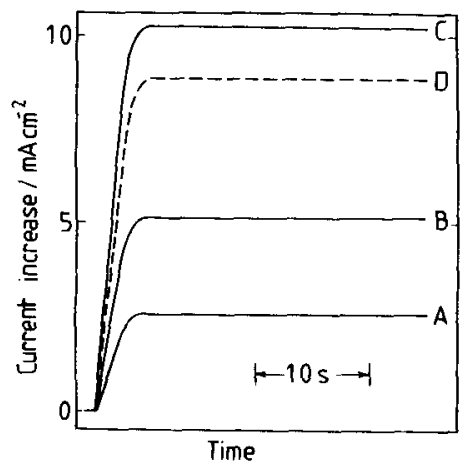

Fig. 1. Electrode response to (A) $0.05 \mathrm{mM}$, (B) 0.1 $\mathrm{mM}$, and (C) $0.2 \mathrm{mM}$ L-lactate, and (D) $0.1 \mathrm{mM} \mathrm{L-}$ ascorbate.

reached a steady state within $5 \mathrm{~s}$. The response on the present electrode was about ten times as quick as that on previous L-lactate-sensing electrodes using immobilized native-LOD ${ }^{5-7)}$. The L-lactate added is expected to diffuse quickly through the thin cellulose acetate/amphiphile layer and be available to be oxidized by the enzyme. Hydrogen peroxide generated by the LOD reaction near the electrode surface is immediately oxidized. These rapid processes result in a fast response on the enzyme electrode.

L-Ascorbate is a typical interferent: its oxidation on the electrode disturbs the anionic indication of hydrogen peroxide. Therefore the electrode response to L-ascorbate was examined. The ratio of response for $0.1 \mathrm{mM} \mathrm{L}$-ascorbate to that for the same concentration of L-lactate was 1.6 , as shown in Fig. 1. The approximate concentrations of Lascorbate and L-lactate in normal sera are $0.05 \mathrm{mM}$ and $1.5 \mathrm{mM}$, respectively. For determining L-lactate in such samples with the enzyme electrode, the level of electrochemical interference by L-ascorbate is expected to be ca. $5 \%$ of the signal output. The electrode would be useful for the rapid estimation of the L-lactate concentration in sera.

Figure 2 shows a calibration graph obtained with the enzyme electrode. The enzyme electrode gave a linear current response up to $0.3 \mathrm{mM}$, and a significant increase in the current was still observed with L-lactate concentration between $0.3-1.0 \mathrm{mM}$. The detection limit was as low as $0.1 \mu \mathrm{M}$. This unusually high senbsitivity (the detection limit with conventional, native LOD-based electrodes has been reported to be $5-10 \mu \mathrm{M}^{5,6)}$ ) is considered to be obtained by the use of a thin layer containing LOD

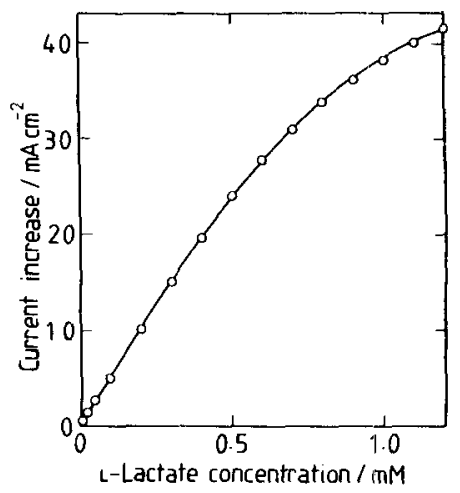

Fig. 2. Calibration graph for L-lactate on the enzyme electrode.

with a high activity $\left(0.2 \mathrm{U} \mathrm{cm}^{-2}\right)$.

The long-term stability of the enzyme electrode was tested by determining $0.1 \mathrm{mM}$ L-lactate five times a day each day for 4 weeks. The average value of the electrode response did not decrease for 10 days. The electrode responses gradually decreased after 10 days, but they are measurable until the end of 4 weeks. The detection limit was lower than $0.3 \mu \mathrm{M}$ on the 28th day. The lifetime, 4 weeks, was compareble to that of previous L-lactate sensors using covalently immobilized $\operatorname{LOD}^{6,7}$ ).

The combination of the modified LOD with a thin polymer overcoat provided an L-lactate-sensing electrode with high performance characteristics such as rapid response, high sensitivity, and high stability.

\section{REFERENCES}

1) L. C. Clark, Ir. and C. A. Duggan, Diabetic Care, 5, 174 (1982).

2) S. Ikeda, K. Ito, T. Kondo, K. Ichikawa, T. Yukawa and H. Ichihashi, Anal. Chem. Symp. Ser., 17, 620 (1983)

3) Y. Okahata, T. Tsuruta, K. Ijiro and K. Ariga, Thin Solid Films, 180, 65 (1989).

4) F. Mizutani, S. Yabuki and T. Katsura, Anal. Chim. Acta, 274, 201 (1993).

5) F. Mizutani, K. Sasaki and Y. Shimura, Anal. Chem., 55, 35 (1983).

6) F. Scheller and F. Schubert, Biosensors, Elsevier, Amsterdam, p. 126 (1992).

7) G. Bardeletti, F. Sechaud and R. P. Coulet, Anal. Chim. Acta, 187, 47 (1986). 